\title{
Peningkatan Pengetahuan dan Sikap Ibu Hamil tentang Anemia pada Kehamilan dengan Media Video dan Lembar Balik
}

\author{
Increased Knowledge and Attitudes of Pregnant Women about Anemia in Pregnancy \\ with Video Media and a Flip Sheet \\ Oktaviani $^{1, \bowtie}$, Maria Julin Rarome ${ }^{1}$ \\ ${ }^{1}$ Jurusan Kebidanan, Politeknik Kesehatan Kementerian Kesehatan Palangka Raya, Indonesia \\ ${ }^{凶}$ Corresponding author: oktaviani.poltekkes@gmail.com
}

Kata kunci:
Anemia pada
kehamilan,
Media video dan
pengetahuan, sikap.

Keyword:

Anemia in pregnancy, video media and knowledge, attitude.

\begin{abstract}
Abstrak
Latar belakang: Tingginya kejadian anemia berkaitan dengan kurangnya gizi pada ibu hamil, diantaranya dipengaruhi oleh pengetahuan dan sikap ibu hamil. Tujuan: Tujuan penelitian ini untuk menganalisis efektivitas media video dan lembar balik terhadap pengetahuan dan sikap ibu hamil tentang anemia pada kehamilan. Metode: Penelitian ini adalah penelitian quasi eksperimen. Sampel kasus adalah ibu hamil yang mengikuti kelas ibu hamil dengan media video $(n=25)$, sedangkan, sampel kontrol adalah ibu hamil yang mengikuti kelas ibu hamil dengan media ceramah lembar balik $(n=25)$. Pemilihan sampel dipilih dengan menggunakan purposive sampling. Analisis bivariat untuk mengetahui perbedaan antar kelompok perlakukan dilakukan dengan uji $T$ independent square. Hasil: Hasil penelitian menunjukkan Ibu hamil yang diberikan pendidikan kesehatan dengan metode video pengetahuannya meningkat 3,85 dibandingkan dengan ibu yang diberikan pendidkan kesehatan dengan lembar balik ( $\mathrm{p}=0,013 ; \mathrm{OR}=3,85)$ dan Ibu hamil dengan metode intervensi video berpeluang 5,63 kali untuk memiliki sikap baik dibandingkan metode lembar balik $(0,008$; OR=3,85). Simpulan: Media pendidikan kesehatan dengan video lebih efektif dibandingkan media lembar balik dalam meningkatkan pengetahuan ibu hamil dan meningkatkan sikap positif pada ibu hamil anemia. Perlu upaya memperbanyak media vidio yang inovatif dalam rangka meningkatkan pengetahuan ibu hamil dan sikap positif.
\end{abstract}

\begin{abstract}
Background: The high prevalence of anemia is related to the lack of nutrition in pregnant women, which is influenced by the knowledge and attitude of pregnant women.. Purpose: The purpose of this study was to analyze the effectiveness of video media on the knowledge and attitudes of pregnant women regarding anemia in pregnancy. Methods: This research is a quasi-experimental study. The case sample is pregnant women who take the class of pregnant women with video media $(n=25)$, while, the control sample is pregnant women who take classes with pregnant women lecture media flipchart $(n=25)$. The sample selection was chosen using purposive sampling. Bivariate analysis to determine differences between treatment groups was performed with the independent square T test. Results: The results showed pregnant women who were given health education with the video method increased knowledge by 3.85 compared to mothers who were given health education with a flipchart $(p=0.013 ; O R=3.85)$ and pregnant women with video intervention methods had a 5.63 times chance to have an attitude better than the flip sheet method (0.008; OR =3.85). Conclusion: Health education media with video is more effective than flipcharts in increasing the knowledge of pregnant women and increasing positive attitudes in anemic pregnant women. Efforts should be made to increase innovative video media in order to increase the knowledge of pregnant women and positive attitudes.
\end{abstract}

Copyright (C) 2019 Jurnal Kesehatan Metro Sai Wawai. All rights reserved. 


\section{Pendahuluan}

Di Indonesia diperkirakan prevalensi kejadian anemia pada ibu hamil sebesar 37,1\% dan proporsinya hampir sama antara di kawasan perkotaan $(36,4 \%)$ dan perdesaan $(37,8 \%)$ (Kementerian Kesehatan RI, 2013). Sedangkan, di Kota Palangka Raya prevalensi anemia pada ibu hamil dengan indikator $\mathrm{HB}<11 \mathrm{gr} \%$ terdapat 2,35\% (Dinas Kesehatan Palangka Raya, 2017).

Ibu hamil yang mengalami anemia meningkatkan risiko mengalami keguguran, melahirkan sebelum waktunya, bayi lahir dengan berat tidak normal, perdarahan sebelum serta pada waktu melahirkan dan pada anemia berat dapat menimbulkan kematian ibu dan bayi. Sedangkan, pada bayi dalam kandungan akan mengalami gangguan pertumbuhan dan perkembangan, tidak dapat mencapai tinggi yang optimal dan anak menjadi kurang cerdas (Prawiroharjo, 2011).

Tingginya kejadian anemia berkaitan dengan kurangnya gizi pada ibu hamil, kurangnya asupan zat besi, mal absorbsi yang rendah. Selain itu, rendahnya pendidikan, informasi dan pengetahuan menyebabkan rendahnya informasi yang diterima (Fajrin, Sudargo, \& Waryana, 2012)

Upaya yang dapat dilakukan untuk meningkatkan pengetahuan ibu hamil tentang anemia adalah melalui pemberian informasi atau pendidikan kesehatan dari tenaga kesehatan. Salah satu faktor yang mempengaruhi proses pendidikan kesehatan adalah alat bantu atau media yang digunakan untuk menyampaikan informasi. Media informasi yang disampaikan secara menarik, dapat membantu penerima informasi mudah menerima dan mempelajari pesan yang disampaikan sehingga mengadopsi perilaku yang positif. Hal ini menyatakan bahwa media yang menarik akan memberikan keyakinan, sehingga perubahan kognitif afeksi dan psikomotor dapat dipercepat (Notoadmojo, 2010).

Media video merupakan media audiovisual merupakan media yang selain mengandung unsur suara juga mengandung unsur gambar yang dapat dilihat, seperti video. Menurut Dwyer dalam (Sadiman, 2010), video mampu merebut 94\% saluran masuknya pesan atau informasi kedalam jiwa manusia melalui mata dan telinga serta mampu untuk membuat orang pada umumnya mengingat $50 \%$ dari apa yang mereka lihat dan dengar dari tayangan program. Pesan yang disampaikan melalui media video dapat mempengaruhi emosi yang kuat dan juga dapat mencapai hasil cepat yang tidak dimiliki oleh media lain. Selain itu, media video dapat meningkatkan pengetahuan karena membangkitkan rangsangan dan motivasi. Hasil penelitian oleh (Ambarawati, Umaroh, Kurniawati, Kuswandari, \& Darojah, 2014) melaporkan bahwa peserta didik sangat tertarik menggunakan video sebesar 52,08\% dibandingkan menggunakan leaflet sebesar $41,67 \%$, karena dalam video memuat banyak gambar dibandingkan menggunakan leaflet. Hasil penelitian oleh (Gunawan, 2016) melaporkan bahwa pendidikan kesehatan dengan menggunakan media video lebih efektif dalam meningkatkan pengetahuan kesehatan gigi dan mulut anak dibandingkan menggunakan media flif chart.

Data studi pendahuluan menemukan bahwa, ibu hamil di wilayah Puskesmas Kereng Bangkirai dari 140 ibu hamil sebanyak 83 orang (59,3\%) tidak tahu mengenai apa itu anemia, penyebab, dan tanda gejala anemia pada masa kehamilan. Mengingat, dampak dari anemia pada masa kehamilan merupakan salah satu penyebab tidak langsung kematian Ibu dan data penelitian sebelumnya menunjukkan masih rendahnya pengetahuan ibu hamil tentang anemia. Oleh karena itu, penelitian ini melakukan analisis dengan tujuan mengidentifikasi efektivitas media pendidikan kesehatan video dan balik lembar terhadap peningkatan pengetahuan dan sikap ibu hamil tentang anemia pada kehamilan.

\section{Metode}

Jenis penelitian ini adalah penelitian eksperimen semu (quasi experimental) rancangan two group comparasion pre test-post test dengan pendekatan yang digunakan adalah kuantitatif. Rancangan ini digunakan untuk memperoleh efektivitas media video dan lembar balik terhadap pengetahuan dan sikap ibu hamil tentang anemia pada kehamilan. 
Sampel kasus pada penelitian ini adalah ibu hamil yang mengikuti kelas ibu hamil dengan media video. Sampel kontrol adalah ibu hamil yang mengikuti kelas ibu hamil dengan media ceramah lembar balik. Besar sampel penelitian ini 50 orang ibu hamil, masing-masing kelompok dengan sampel sejumlah 25 orang ibu hamil. Pemilihan sampel dipilih dengan menggunakan purposive sampling.

Prosedur penelitian ini dimulai dengan memilih Ibu hamil dan dikelompokan sesuai dengan kriteria yang sudah ditentukan. Pada tahapan selanjutnya, kelompok yang diberikan perlakuan media video dan perlakuan media lembar balik diberikan penjelasan mengenai proses penelitian yang akan dilaksanakan. Kemudian, pada saat pelaksanaan kelas ibu hamil sesuai jadwal masing-masing kelompok akan diberikan kuesioner pre test sebelum diberikan perlakuan. Setelah diberikan pre test, setiap kelompok diberikan perlakukan sesuai dengan kelompoknya. Setelah diberikan perlakukan responden diberikan kuesioner untuk post test. Pengukuran data menggunakan instrumen kuesioner.

Data yang telah dikumpulkan dilakukan analisis dengan analisis univariat dengan distibusi frekuensi (persentasi) dan analisis bivariat. Analisis data bivariat menggunakan uji dengan uji tindependent untuk efektivitas media video dan lembar balik terhadap pengetahuan dan sikap ibu hamil tentang anemia pada kehamilan.

\section{Hasil}

\section{Karakteristik responden}

Hasil penelitian pada karakteristik responden menunjukkan bahwa, usia ibu hamil lebih banyak tidak berisiko, baik pada kelompok video sebanyak 72\% dan pada kelompok lembar balik sebanyak 96\%. Pada kelompok video sebanyak $76 \%$ ibu hamil berpendidikan tinggi dan pada kelompok lembar balik sebanyak $40 \%$ ibu hamil berpendidikan tinggi. Status pekerjaan ibu hamil pada kelompok video yang tidak berkerja sebanyak $72 \%$ dan pada kelompok lembar balik yang tidak bekerja sebanyak $84 \%$. Ibu hamil dengan multipara pada kelompok video sebanyak $60 \%$ dan ibu hamil multipara pada kelompok lembar balik sebanyak 64\%.

Tabel 1.

Distribusi karakteristik ibu hamil pada kelompok perlakuan dan kontrol

\begin{tabular}{lcccc}
\hline \multicolumn{1}{c}{ Variabel } & \multicolumn{2}{c}{ Video } & \multicolumn{2}{c}{ Lembar Balik } \\
\cline { 2 - 5 } & $\mathbf{n}$ & $\mathbf{\%}$ & $\mathbf{n}$ & $\mathbf{\%}$ \\
\hline Usia & 18 & $72 \%$ & 24 & $96 \%$ \\
$\quad$ Tidak Berisiko & 7 & $28 \%$ & 1 & $4 \%$ \\
$\quad$ Berisiko & & & & \\
Pendidikan & 19 & $76 \%$ & 10 & $40 \%$ \\
$\quad$ Tinggi & 6 & $24 \%$ & 15 & $60 \%$ \\
$\quad$ Dasar-Menengah & & & & \\
Pekerjaan & 18 & $72 \%$ & 7 & $28 \%$ \\
$\quad$ Bekerja & 7 & $28 \%$ & 18 & $72 \%$ \\
$\quad$ Tidak Bekerja & & & & \\
Paritas & 2 & $8 \%$ & 4 & $16 \%$ \\
$\quad$ Grandepara & 15 & $60 \%$ & 16 & $64 \%$ \\
$\quad$ Multipara & 8 & $32 \%$ & 5 & $20 \%$ \\
$\quad$ Primipara & & &
\end{tabular}

\section{Gambaran peningkatan pengetahuan dan sikap ibu hamil}

Gambar 1 memperlihatkan bahwa sebelum masa intervensi, pada kelompok video, ibu hamil dengan pengetahuan baik sebanyak $20 \%$ dan pada kelompok lembar balik ibu hamil dengan pengetahuan baik sebanyak $24 \%$. Setelah masa intervensi pada kelompok video, ibu hamil dengan pengetahuan baik meningkat menjadi sebanyak $60 \%$ dan pada kelompok lembar balik pula meningkat dengan pengetahuan baik sebanyak 28\%. Sedangkan, gambar 2 menunjukkan bahwa sebelum intervensi 
pada kelompok video, ibu hamil yang memiliki sikap baik sejumlah $16 \%$ dan pada kelompok lembar balik ibu hamil dengan sikap baik sebanyak $40 \%$. Setelah intervensi pada kelompok video, ibu hamil dengan sikap baik meningkat menjadi $64 \%$ dan pada kelompok lembar balik ibu hamil dengan sikap baik mengalami penurunan menjadi $24 \%$.

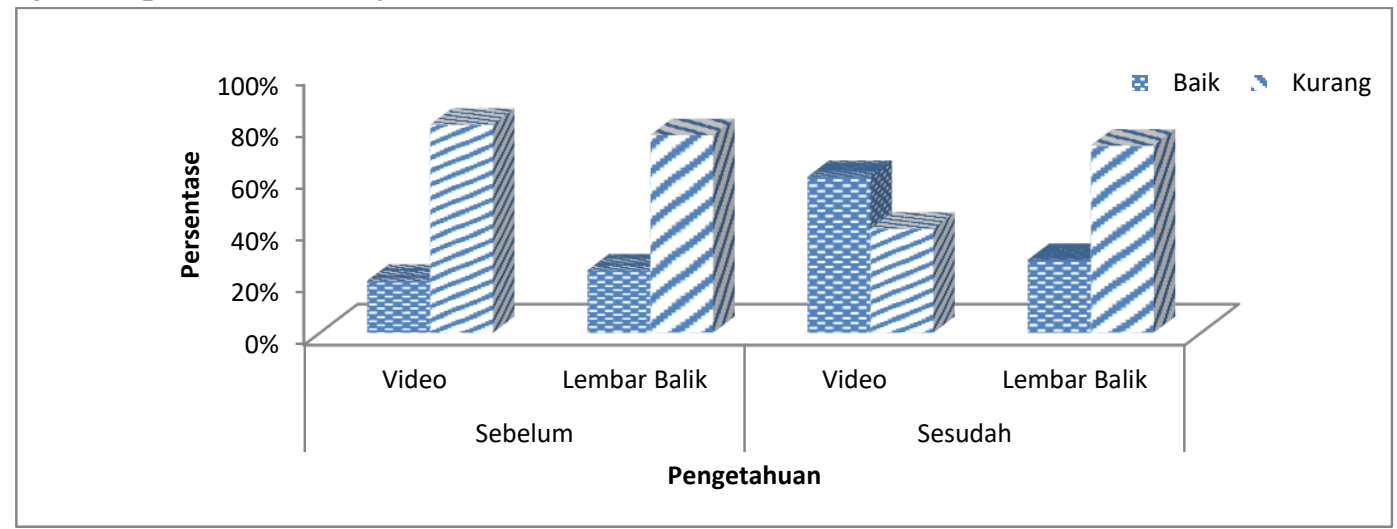

Gambar 2.

Perbandingan visual respons sikap ibu hamil sebelum dan sesudah intervensi pada dua kelompok intervensi

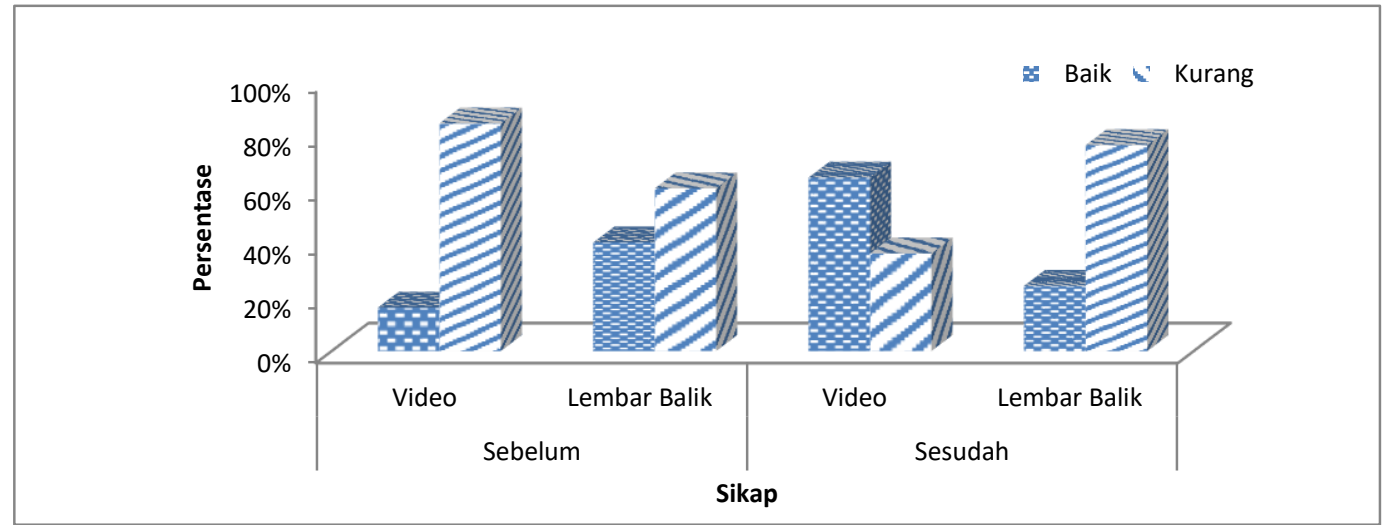

Gambar 2.

Perbandingan visual respons sikap Ibu Hamil sebelum dan sesudah Intervensi pada dua kelompok intervensi

\section{Hasil analisis bivariat}

Tabel 2 memperlihatkan hasil analisis penelitian yang menunjukkan ada hubungan signifikan antara metode video dan lembar balik dengan pengetahuan ibu ( $\mathrm{p}$ value 0,046$)$. Ibu hamil yang diberikan pendidikan kesehatan dengan metode menggunakan video pengetahuannya meningkat lebih baik 3,85 kali dibandingkan dengan ibu yang diberikan pendidikan kesehatan dengan lembar balik (OR 3,85).

Hasil penelitian pada tabel 3 menjelaskan hasil analisis hubungan metode promosi dengan sikap ibu menunjukkan hasil, sebanyak $64 \%$ ibu dengan metode video memiliki sikap baik dan $24 \%$ ibu dengan metode lembar balik memiliki sikap baik. Terdapat hubungan signifikan antara metode pendidikan kesehatan dengan media lembar balik dengan sikap ibu ( $\mathrm{p}$ value 0,010 ). Ibu hamil dengan metode intervensi menggunakan media video berpeluang 5,63 kali untuk memiliki sikap baik dibandingkan metode lembar balik (OR 5,63).

\section{Pembahasan}

Efektifitas media video dan lembar balik dalam meningkatkan pengetahuan dan sikap ibu hamil

Salah satu faktor yang mempengaruhi proses pendidikan kesehatan adalah alat bantu atau media yang digunakan untuk menyampaikan informasi. Hasil penelitian menunjukkan setelah diberikan intervensi pada kelompok media video bahwa ibu hamil dengan pengetahuan baik meningkat menjadi 
Tabel 2.

Analisis hubungan metode pendidikan kesehatan terhadap pengetahuan ibu

\begin{tabular}{|c|c|c|c|c|c|c|}
\hline \multirow{3}{*}{ Variabel } & \multicolumn{4}{|c|}{ Pengetahuan } & \multirow{3}{*}{$\begin{array}{l}\text { Odd Ratio } \\
(95 \% \text { CI })\end{array}$} & \multirow{3}{*}{$P$ Value } \\
\hline & \multicolumn{2}{|c|}{ Baik } & \multicolumn{2}{|c|}{ Kurang } & & \\
\hline & $\mathbf{n}$ & $\%$ & $\mathbf{n}$ & $\%$ & & \\
\hline \multicolumn{7}{|c|}{ Pengetahuan Metode } \\
\hline Video & 15 & 60 & 10 & 40 & 3,85 & 0,046 \\
\hline Lembar Balik & 7 & 28 & 18 & 72 & $(1,18-12,6)$ & \\
\hline
\end{tabular}

Tabel 3.

Analisis hubungan metode promosi terhadap sikap ibu

\begin{tabular}{|c|c|c|c|c|c|c|}
\hline \multirow{3}{*}{ Variabel } & \multicolumn{4}{|c|}{ Sikap } & \multirow{3}{*}{$\begin{array}{l}\text { Odd Ratio } \\
(95 \% \text { CI) }\end{array}$} & \multirow{3}{*}{$P$ Value } \\
\hline & \multicolumn{2}{|c|}{ Baik } & \multicolumn{2}{|c|}{ Kurang } & & \\
\hline & $\mathbf{n}$ & $\%$ & n & $\%$ & & \\
\hline \multicolumn{7}{|l|}{ Sikap Metode } \\
\hline Video & 16 & 64 & 9 & 36 & 5,63 & 0,010 \\
\hline Lembar Balik & 6 & 24 & 16 & 76 & $(1,64-19,23)$ & \\
\hline
\end{tabular}

sebanyak $60 \%$ dan pada kelompok lembar balik juga meningkat dengan pengetahuan baik sebanyak $28 \%$. Hasil ini menunjukkan bahwa ibu hamil yang diberikan penyuluhan dengan menggunakan media akan meningkatkan pengetahuan ibu hamil tentang anemia pada kehamilan. Penelitian juga memperoleh hasil menunjukkan bahwa ada hubungan signifikan antara metode video dan lembar balik dengan pengetahuan ibu tentang anemia kehamilan.

Penelitian oleh (Niken, 2012) melaporkan bahwa media video lebih baik dari pada media leaflet untuk meningkatkan pengetahuan ibu hamil tentang cara mengatasi keluhan pada masa kehamilan di RSUD Kota Surakarta. (Notoadmojo, 2010) menjelaskan bahwa pendidikan kesehatan merupakan suatu kegiatan menyampaikan pesan kepada individu, keluarga atau masyarakat dengan harapan dapat memperoleh pengetahuan tentang kesehatan lebih baik. Pendidikan kesehatan tidak lepas dari media karena melalui media, pesan-pesan yang disampikan dapat lebih menarik dan dipahami sehingga sasaran dapt lebih baik mempelajari pesan tersebut, sehingga sampai memutuskan untuk mengadopsi perilaku positif.

Hasil analisis juga menunjukkan bahwa ibu dengan metode pendidikan kesehatan menggunakan video berpeluang 3,85 untuk memiliki pengetahuan baik dibandingkan dengan ibu yang diberikan lembar balik. Hasil penelitian mendukung penelitian oleh (Fatmah, 2017) bahwa media audiovisual sangat efektif digunakan untuk meningkatkan pengetahuan ibu hamil. Media video merupakan media yang menyajikan audio dan visual yang berisi pesan-pesan baik yang berisi konsep, prinsip, prosedur, teori aplikasi, pengetahuan untuk membantu pemahaman terhadap suatu materi pembelajaran. Media video mampu meningkatkan motivasi dan efektivitas penggunaannya sebagai media pembelajaran (Sadiman, Rahardjo, Harjono \& Harijo, 2010). (Kholid, 2012) mengungkapkan bahwa sebesar 20\% orang mengingat dari apa yang mereka dengar, $30 \%$ dari apa yang mereka lihat dan sebesar $70 \%$ dari apa yang mereka dengar dan lihat.

Menurut (Sadiman, Rahardjo, Harjono \& Harijo, 2010) media video merupakan media yang menyajikan audio dan visual yang berisi pesan-pesan baik yang berisi konsep, prinsip, prosedur, teori aplikasipengetahuan untuk membantu pemahaman terhadap suatu materipelajaran. Video merupakan bahan pembelajaran tampak dengar (audiovisual) yang dapat digunakan untuk menyampaikan pesanpesan/materi pelajaran. mampu meningkatkan motivasi dan efektivitas penggunanya. Dengan demikian, media video sebagai audiovisul yang mampu menstimulasi panca indera pendengaran maupun penglihatan, sehingga lebih menarik dan hasil yang diperoleh lebih optimal, dibandingkan dengan media 
lembar balik. Meningkatnya pengetahuan ibu hamil menunjukkan bahwa intervensi pendidikan kesehatan dengan media vidio yang diberikan kepada ibu hamil dapat diulang-ulang dan cara penyampaian yang tepat dapat memberikan hasil penelitian yang lebih baik dibandingkan dengan lembar balik.

\section{Efektifitas media video dan lembar balik terhadap sikap ibu hamil}

Pada variabel sikap ibu hamil dari hasil penelitian menunjukkan bahwa terdapat perbedaan sebelum masa intervensi, pada kelompok video, ibu hamil dengan sikap baik sebanyak $16 \%$ dan pada kelompok lembar balik ibu hamil dengan sikap baik sebanyak 40\%. Setelah masa intervensi pada kelompok video, ibu hamil dengan sikap baik sebanyak 64\% dan pada kelompok lembar balik ibu hamil dengan sikap baik mengalami penurunan menjadi $24 \%$. Hasil penelitian pada kelompok kontrol dengan intervensi media lembar balik. Hasil ini sejalan dengan penelitian oleh (Fatmah, 2017) terdapat peningkatan sikap baik ibu tentang inisiasi menyusu dini yang diberikan intervensi menggunakan media video sebelum 46,7\% dan setelah intervensi 83,3\%. Domain pengetahuan mendasari sikap seseorang dan keduanya merupakan domain yang sangat penting dalam membentuk prilaku atau tindakan seseorang (Notoadmojo, 2010). Artinya sikap baik atau positif ibu hamil yang didasari pengetahuan akan semakin membentuk sikap yang menetap. Media audiovisual sangat efektif digunakan untuk meningkatkan pengetahuan ibu hamil dan perubahan sikap positif (Fatmah, 2017). Penelitian (Jino, Munyanshongore, \& Birungi, 2013) juga melaporkan bahwa semakin tinggi pengetahuan ibu hamil akan semakin mendukung sikap ibu hamil.

Pada variabel sikap hasil penelitian menunjukan ada hubungan signifik1an antara metode video dan lembar balik dengan pengetahuan ibu ditunjukkan dengan $\mathrm{p}$ value 0,046 . Ibu dengan metode video berpeluang 3,85 untuk memiliki sikap baik dibandingkan dengan ibu yang diberikan lembar balik. Sikap merupakan suatu reaksi atau respon yang muncul dari seseorang individu terhadap objek yang kemudian memunculkan perilaku individu terhadap objek tersebut dengan cara-cara tertentu. Perubahan sikap salah satunya dipengaruhi oleh informasi yang didapatkan dari media sehingga meningkatkan pengetahuan seseorang (Azwar, 2013). Penelitian oleh (Kapti, Rustina, \& Widyatuti, 2013) melaporkan hal yang sejalan dengan hasil penelitian ini bahwa media yang menarik akan memberikan keyakinan pada masyarakat sehingga terjadi perubahan pengetahuan, sikap dan keterampilan dapat dipercepat.

Hasil penelitian menunjukkan bahwa media video dan lembar balik menunjukkan terdapat hubungan bermakna terhadap pengetahuan dan sikap ibu hamil. Hasil ini sejalan dengan penelitian oleh (Nivedita \& Fatimah, 2016) dalam studi yang mereka perlakukan pada 316 Ibu Hamil di Rumah Sakit Pendidikan Sri Manakula Vinayagar, Puducherry, India. Bahwa, ada peningkatan pengetahuan terhadap anemia, dan sikap yang mengarah kepada perubahan pengaturan pola makan, termasuk pemilihan suplemen. Peningkatan sikap positif ibu hamil kemungkinan dapat menyebabkan peningkatan sikap ibu hamil tentang anemia ibu hamil, karena terjadi peningkatan pengetahuan pada ibu hamil. Menurut Azwar (2009) pengetahuan yang baik akan mempengaruhi seseorang untuk memiliki sikap positif terhadap objek tertentu.

Media yang digunakan dalam pendidikan kesehatan, yakni video dan lembar balik yang efektif secara makna dalam perubahan sikap, baik sebelum maupun sesudah intervensi dilakukan. Implikasi temuan ini secara strategis tidak membedakan jenis media. Dengan demikian dapat dikatakan bahwa, jenis media yang digunakan, memiliki efektifitas yang cenderung sama untuk digunakan sebagai media promosi atau penyuluhan. (Baizhumanova, et al., 2010) menyatakan bahwa penting untuk dilakukan pernyuluhan, sehingga perubahan sikap membawa kepada kesadaran diri responden di Kyzyl-Orda terhadap defisiensi zat besi, menjadi lebih tinggi. Lebih lanjut disampaikan, bahwa kejadian defisiensi zat besi mengalami penurunan bermakna selama masa studi. Oleh karena itu, keberhasilan pendidikan kesehatan ibu hamil dipengaruhi oleh komponen proses pembelajaran. Media pendidikan kesehatan sebagai bagaian komponen dari proses pembelajaran dalam meningkatkan pengetahuan dan sikap positif 
ibu hamil. Pemilihan media pendidikan kesehatan sangat perlu mempertimbangkan sasaran dan tujuan, sehingga perubahan pengetahuan dan sikap dapat optimal dan perubahan prilaku yang diharapkan dapat menjadi kenyataan dalam rangka meningkatkan derajat kesehatan masyarakat secara umum.

\section{Simpulan dan saran}

Media pendidikan kesehatan dengan video dan lembar balik meningkatkan pengetahuan dan sikap positif ibu hamil. Media pendidikan kesehatan dengan video lebih efektif dibandingkan media lembar balik dalam meningkatkan pengetahuan ibu hamil dan meningkatkan sikap positif pada ibu hamil anemia. Pendidikan kesehatan untuk peningkatan pengetahuan dan sikap ibu hamil, perlu mempertimbangkan media yang yang lebih tepat dan lebih efektif, diantaranya adalah dengan media video dibandingkan lembar balik. Namun demikian, tetap memperhatikan tujuan dan sasaran dalam memilih media untuk pendidikan kesehatan.

\section{Referensi}

Ambarawati, Umaroh, A. K., Kurniawati, F., Kuswandari, T. D., \& Darojah, S. (2014). Media leaflet, video dan pengetahuan siswa SD tentang bahaya merokok (Studi pada Siswa SDN 78 Sabrang Lor Mojosongo Surakarta). Jurnal Kesehatan Masyarakat, 10, 7-13. doi:https://doi.org/10.15294/kemas.v10i1.3064

Azwar, S. (2013). Sikap Manusia Teori dan Pengukurannya (2 ed.). Yogyakarta: Pustaka Pelajar.

Baizhumanova, A., Nishimura, A., Ito, K., Sakamoto, J., Karsybekova, N., Tsoi, I., \& Hamajima, N. (2010). effectiveness of communication campaign on iron deficiency anemia in kyzyl-Orda Region, Kzakhstan: a Pilot Study. Journal BMC Blood Disord, 10, 1-8. doi:10.1186/1471-2326-10-2

Dinas Kesehatan Palangka Raya. (2017). Profil kesehatan kota Palangka Raya. Palangka Raya: Dinkes Palangka Raya.

Fajrin, A., Sudargo, T., \& Waryana. (2012). Faktor risiko sosial ekonomi, asupan zat besi terhadap kejadian anemia pada anak sekolah Dasar. Jurnal Gizi Indonesia. 35(1), 22-29. DOI: 10.36457/gizindo.v35i1.120

Gunawan, P. N. (2016). perbandingan efektivitas pendidikan kesehatan gigi menggunakan media video dan flip chart terhadap peningkatan pengetahuan kesehatan gigi dan mulut anak. Jurnal Egigi, VI. Retrieved from http://ejournal.unsrat.ac.id/inde x.php/egigi/article/view/13490

Jino, G. B., Munyanshongore, C., \& Birungi, F. (2013). Knowledge, attitudes and practices of exclusive breastfeeding of infants aged 0-6 months by urban refugee women In Kigali. RJM, 7-10.

Kapti, R. E., Rustina, Y., \& Widyatuti. (2013). Efektivitas audiovisual sebagai media penyuluhan kesehatan terhadap peningkatan pengetahuan dan sikap ibu dalam tatalaksana balita dengan diare di dua Rumah Sakit Kota Malang. Jurnal Ilmu Keperawatan. 1(1). 53-60

Kementerian Kesehatan RI. (2013). Riset kesehatan dasar (Riskesdas). Jakarta: Badan Penelitian dan Pengembangan Kesehatan.

Kholid, A. (2012). Promosi kesehatan: dengan pendekatan teori perilaku, media dan aplikasinya untuk mahasiswa dan praktisi kesehatan. Jakarta: Rajawali Press.

Niken, P. (2016). pengaruh konseling menggunakan lembar balik dan leaflet terhadap kepatuhan ibu hamil mengkonsumsi tablet besi. Jurnal Elektronik, VI.

Nivedita, K., \& Fatimah, S. N. (2016). Knowledge, attitude and practices of pregnant women regarding anemia, iron rich diet and iron supplements and its impact on their hemoglobin levels. 5, 452-431.

Notoadmojo, S. (2010). Ilmu perilaku kesehatan. Jakarta: PT Rineka Cipta.

Sadiman, A.S., Rahardjo, R., Harjono, A. \& Harijo. (2010). Media pendidikan. Jakarta: Rajawali Pers.

Prawiroharjo, S. (2011). Ilmu kebidanan. Jakarta: Yayasan Bina Pustaka Sarwono Prawirohardjo.

Zakaria, F. (2017). Pengaruh pendidikan kesehatan dengan media audio visual terhadap pengetahuan dan sikap tentang inisiasi menyusu dini di Kota Yogyakarta. Thesis. Program Studi Magister Kebidanan Program Pasca Sarjana Universitas 'Aisyiyah Yogyakarta. Retrieved from hhttp://digilib.unisayogya.ac.id/ pdf 